Bons, G. V. R. (1952). J. gen. Microbiol. 6, 344-351.

\title{
The Extracellular Bacteriolytic Enzymes of a Species of Streptomyces
}

\author{
By G. V. R. BORN* \\ Sir William Dunn School of Pathology, University of Oxford
}

SUMMARY: A bacteriolytic protease produced by a species of Streptomyces is activated by manganese and other metals. This enzyme digests autoclaved Bacterium coli but not autoclaved Staphylococcus aureus, though it does digest 'proteins' extracted from staphylococci with hot alkali. A ribonuclease is produced by the Streptomyces sp. but it apparently takes no part in the lysis of Staph. aureus. During lysis autoclaved Bact. coli do not disintegrate but progressively diminish in size.

Culture filtrates of actinomycetes are known to lyse heat-killed bacteria, Gram-negative organisms being far more readily lysed than Gram-positive ones (Waksman, 1947; Welsch, 1947; Jones, Swallow \& Webb, 1948). Tai \& van Heyningen (1951) showed that a species of Streptomyces produced at least two proteolytic enzymes, the action of which could account for all the lysis of heat-killed Gram-negative organisms. One of these enzymes acted upon casein and the other had a greater affinity for protein(s) present in Bact. coli, but the caseinolytic enzyme may also have been bacteriolytic. The possibility that other, non-proteolytic, enzymes were concerned in bacteriolysis could not be excluded, although polysaccharases were apparently not involved. Heat-killed Gram-positive organisms were far less susceptible to lysis by the streptomyces enzymes. Jones et al. (1948) suggested that such organisms are lysed by proteolytic enzymes only after they have been made Gram-negative by the action of ribonuclease. In support of this suggestion they demonstrated that the filtrates of 35-day cultures of an Actinomyces sp. contained a ribonuclease and that lysis of Gram-positive organisms was brought about only with these filtrates and not with those obtained from 50-day cultures which did not contain ribonuclease. They did not show that ribonuclease actually participated in the lysis, nor did they show that the actinomyces ribonuclease changed the organisms from Gram-positive to Gramnegative during lysis. Dubos (1937) showed that pneumococci which had been lysed by crystalline trypsin to the extent of losing $75 \%$ of their weight and $92 \%$ of their nitrogen were still Gram-positive entities, and Welsch (1947) found that heat-killed staphylococci could be lysed by the enzyme system of a Streptomyces sp. and still remain Gram-positive. He also found that staphylococci made Gram-negative by treatment with bile salts at $60^{\circ}$ were no more sensitive to his enzyme system than untreated controls.

It has now been found that, of the two streptomyces proteases demonstrated by Tai \& van Heyningen (1951), the one which readily attacks the protein(s) present in Bact. coli is activated by manganese and other metals, while the

* Present address : Department of Pharmacology, University of Oxford. 
caseinolytic protease is inhibited by manganese and more or less unaffected by other metals. The lysis of a heat-killed Gram-positive organism (Staph. aureus) is not activated by manganese, although the digestion of proteins extracted from this organism with hot alkali is activated by manganese. Attempts to purify and separate these two proteolytic enzymes of this Streptomyces sp. have met with only limited success. A ribonuclease has been demonstrated in the culture filtrate but it does not appear to participate in the lysis of staphylococci. During lysis of Gram-negative organisms there does not appear to be any dissolution of the organism, but rather a diminution in size.

\section{METHODS}

\section{Lytic preparations and estimations of lytic activities}

The culture of Streptomyces used was that of Tai \& van Heyningen (1951), and their methods were used for producing lytic filtrates, concentrating the lytic enzymes and determining bacteriolytic and proteolytic activities. Bacteriolytic activity was estimated by measuring the percentage lysis, i.e. percentage decrease in turbidity, of a standard suspension of autoclaved Bact. coli, caused by the lytic preparation in $15 \mathrm{~min}$. under defined conditions. Casein and autoclaved Bact. coli were used as substrates for the proteolytic enzymes, and the activity of these enzymes was estimated by measuring the increase in trichloroacetic acid-soluble products, formed during digestion for $20 \mathrm{~min}$. under defined conditions, by the spectrophotometric method of Kunitz (1947).

Ribonuclease estimations were made by a method described by Born (1951). It consists in digesting yeast ribonucleic acid with samples of the unknown ribonuclease and of a standard preparation of the enzyme and comparing the turbidities that are produced when the undigested nucleic acid is precipitated with $\mathrm{HCl}$ under defined conditions. The method is not described since little use was made of it in the work to be reported here.

Other determinations. Bacterial counts were done in a Helber chamber with dark-ground microscopy. Nitrogen was determined by the micro-Kjeldahl method. Values of $\mathrm{pH}$ were determined electrometrically with a glass electrode. Manganese was determined by the method of Stockdale \& Dexter (1938).

\section{RESULTS}

Comparison of the rates of lysis of Gram-positive and Gram-negative organisms Suspensions of autoclaved Bact. coli and Staph. aureus (0.63 mg. dry wt./ml.) were treated with the streptomyces enzyme preparation or with crystalline trypsin $\left(30 \mu \mathrm{g} . / \mathrm{ml}\right.$.) for $30 \mathrm{~min}$. at $37^{\circ}$ and the rates of lysis compared. (According to Vendrely (1946) the protein contents of coliform bacilli and staphylococci are both about $75 \%$ of the dry weight.) Table 1 shows that the streptomyces preparation lysed the Gram-negative organism 3 times as fast as the Gram-positive and that with trypsin the difference in rates was 2-fold.

When a lower concentration of the streptomyces enzymes acted upon these substrates for a longer time the difference in rates of lysis of Gram-negative 
and Gram-positive organisms was not so great, as can be seen in Table 2. (These experiments were carried out with aseptic precautions.)

Table 1. Lysis of autoclaved Bact. coli and Staph. aureus by a streptomyces preparation and by crystalline trypsin (30 min. at $37^{\circ}$ )

\begin{tabular}{|c|c|c|}
\hline \multirow[b]{2}{*}{ Substrate } & \multicolumn{2}{|c|}{ Lysis (\%) with } \\
\hline & $\begin{array}{l}\text { Streptomyces } \\
\text { preparation }\end{array}$ & Trypsin \\
\hline $\begin{array}{l}\text { Bact. coli } \\
\text { Staph. aureus }\end{array}$ & $\begin{array}{l}77 \\
\mathbf{2 4}\end{array}$ & $\begin{array}{l}50 \\
\mathbf{2 5}\end{array}$ \\
\hline
\end{tabular}

Table 2. Lysis of autoclaved Bact. coli, Staph. aureus and Strep. pyogenes by a smaller concentration of the streptomyces preparation than that used in the experiments shown in Table 1

\begin{tabular}{|c|c|c|c|}
\hline \multirow[b]{2}{*}{$\begin{array}{l}\text { Time } \\
\text { (br.) }\end{array}$} & \multicolumn{3}{|c|}{ Lysis (\%) of } \\
\hline & $\begin{array}{c}\text { Bact. } \\
\text { coli }\end{array}$ & $\begin{array}{l}\text { Staph. } \\
\text { aureus }\end{array}$ & $\begin{array}{r}\text { Strep. } \\
\text { pyogene }\end{array}$ \\
\hline 4 & 62 & 43 & 23 \\
\hline 16 & 80 & 70 & 61 \\
\hline 32 & 85 & 74 & 66 \\
\hline
\end{tabular}

Table 3. Effect of various metal ions (at $0.002 \mathrm{M})$ on the proteolytic digestion of autoclaved Bact. coli by the streptomyces preparation

\begin{tabular}{lc} 
& $\begin{array}{c}\text { Ratio: } \\
\text { Metal }\end{array}$ \\
\cline { 2 - 2 } activity +metal \\
Manganese & $\mathbf{3}$ activity-metal \\
Magnesium & $2 \cdot 10$ \\
Iron & 1.45 \\
Calcium & $1 \cdot 44$ \\
Copper & $1 \cdot 16$ \\
Cobalt & 1.00 \\
Zinc & 0.98
\end{tabular}

\section{Activation of bacteriolysis by metals}

The effect of various metal ions on the proteolytic digestion of autoclaved Bact. coli by the streptomyces preparation was investigated. The effect of metals on the lysis of autoclaved Bact. coli could not be studied because addition of metal salts to the bacterial suspension caused variable changes in turbidity and interfered with the turbidimetric assay of bacteriolysis. Table 3 shows that manganese and some other metals had a considerable activating effect on the proteolysis of autoclaved Bact. coli.

Although emission spectroscopy (kindly carried out by Dr F. M. Brewer) showed no traces of manganese either in the streptomyces enzyme preparation or in the autoclaved Bact. coli substrate, various metal-binding compounds partially inhibited the action of the enzyme when no metals were added (Table 4). This inhibition may have been due to the removal of traces of other activating metals, such as magnesium or calcium, which were shown to be present. 
Table 4. Effect of metal-binding substances on the digestion of autoclaved Bact. coli by the streptomyces preparation

Ratio:

Substance

Ethylenediamine tetra-acetate

Citrate

Thiolacetate

Cysteine

Oxalate

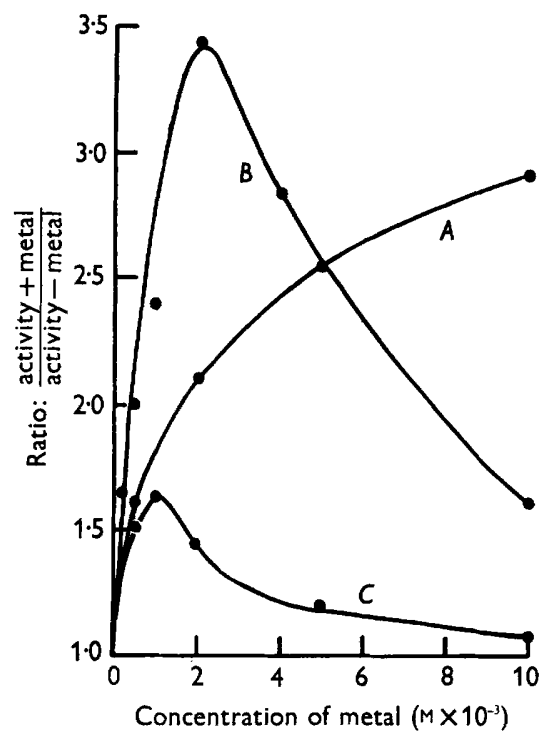

Fig. 1

\begin{tabular}{|c|c|}
\hline $\begin{array}{l}\text { Concentration } \\
\text { (M) }\end{array}$ & $\frac{\text { activity + substance }}{\text { activity - substance }}$ \\
\hline 0.005 & 0.40 \\
\hline $0 \cdot 10$ & 0.52 \\
\hline $0 \cdot 0025$ & 0.54 \\
\hline 0.0025 & $0 \cdot 70$ \\
\hline $0 \cdot 000125$ & 0.80 \\
\hline
\end{tabular}

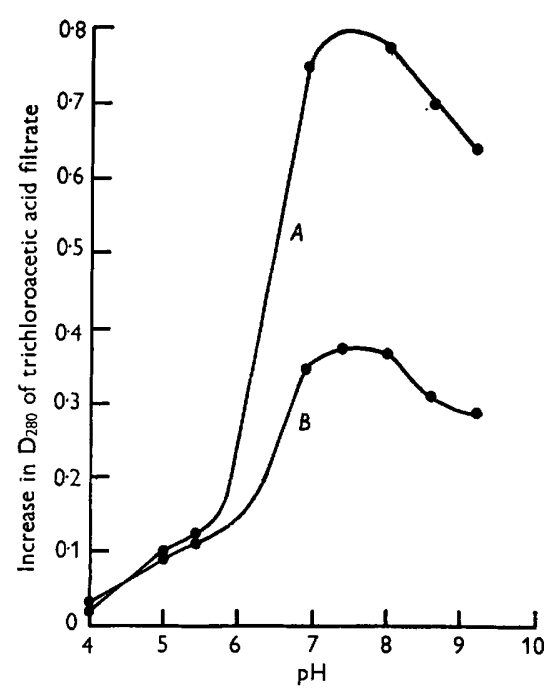

Fig. 2

Fig. 1. Activation of the proteolytic digestion of autoclaved Bact. coli by the streptomyces preparation in the presence of magnesium $(A)$, manganese $(B)$ and calcium $(C)$.

Fig. 2. Effect of $\mathrm{pH}$ on the proteolytic digestion of autoclaved Bact. coli by the streptomyces preparation in the presence $(A)$ and in the absence $(B)$ of manganese.

Fig. 1 shows that the optimum concentration of manganese for the proteolysis of autoclaved Bact. coli was about $0.002 \mathrm{M}$. Fig. 2 shows that manganese did not affect the optimum $\mathrm{pH}$ for this proteolysis. Dialysis for $24 \mathrm{hr}$. decreased the concentration of manganese from $0.002 \mathrm{M}$ to a level too low to estimate and completely reversed the activation. The effect of manganese on the digestion of several other proteins besides autoclaved Bact. coli was tested, with the results shown in Table 5. It is interesting to note that it was only the proteolysis of autoclaved Bact. coli which was activated, whereas the digestion of several other proteins, including casein, was inhibited. Other metals did not affect the digestion of casein.

Table 6 shows that manganese had no effect on the proteolysis of autoclaved Bact. coli by a crystalline protease of Aspergillus oryzae (kindly supplied by Dr W. G. Crewther; see Crewther \& Lennox, 1950) or by crystalline trypsin. 
At this stage it was clear that the manganese-activated enzyme in the streptomyces preparation was that which acted upon the protein(s) present in autoclaved Bact. coli and that several substrates from sources other than bacteria were not attacked by it. It was, therefore, interesting to find out whether this enzyme also acted on proteins of Gram-positive organisms.

Table 5. Effect of manganese $(0.002 \mathrm{M})$ on the digestion of various proteins by the streptomyces preparation

\begin{tabular}{lc}
$\quad$ Substrate & $\begin{array}{c}\text { Ratio: } \\
\text { activity }+\mathbf{M n}\end{array}$ \\
\cline { 2 - 2 } Activity $-\mathbf{M n}$
\end{tabular}

Table 6. Effect of manganese (0.002 $\mathrm{M}$ ) on the digestion of autoclaved Bact. coli by protease from Aspergillus oryzae and by trypsin

\begin{tabular}{lcc}
\multicolumn{1}{c}{ Enzyme } & $\begin{array}{c}\text { Final } \\
\text { concentration } \\
\text { of enzyme } \\
(\mu \mathrm{g} . / \mathrm{ml} .)\end{array}$ & $\begin{array}{c}\text { Ratio: } \\
\text { activity }+\mathbf{M n}\end{array}$ \\
$\begin{array}{lcc}\text { activity }-\mathbf{M n} \\
\text { T. oryzae protease }\end{array}$ & 10 & 1.00 \\
Trypsin & 5 & 0.81
\end{tabular}

Suspensions of autoclaved Bact. coli and Staph. aureus (0.5\% dry wt./vol.) were treated with the streptomyces enzyme preparation with and without the addition of $0.002 \mathrm{M}$ manganese, for $20 \mathrm{~min}$. in the case of Bact. coli and for $60 \mathrm{~min}$. in the case of Staph. aureus. After these times the mixtures were precipitated with an equal volume of $10 \%(\mathrm{w} / \mathrm{v})$ trichloroacetic acid and the ultraviolet absorption spectra of the filtrates determined. These showed that whereas the digestion of Bact. coli was activated by manganese there was no activation in the case of Staph. aureus (Fig. 3).

These results suggested that Gram-positive organisms are lysed more slowly than Gram-negative organisms because the manganese-activated enzyme does not participate in the proteolysis of the former. The results do not necessarily mean that Gram-positive organisms do not contain the substrate of the manganese-activated enzyme. It is possible that the substrate is present but protected from the action of the enzyme. Some light is shed on this point by the following experiment. Autoclaved Staph. aureus suspensions were treated with $0.5 \mathrm{~N}-\mathrm{NaOH}$ for $20 \mathrm{~min}$. at $56^{\circ}$ and at $100^{\circ}$ and centrifuged. The insoluble residues and the supernatants were neutralized and dialysed for $48 \mathrm{hr}$. against running tapwater and then digested with the streptomyces preparation with and without $0.002 \mathrm{M}$ manganese. The results are shown in Table 7. Proteolysis of fractions obtained at $56^{\circ}$ was unaffected by manganese, but the fractions obtained at $100^{\circ}$ were readily digested by the manganese-activated enzyme. 
Whether this was due to the destruction or removal of an inhibitor or to an alteration of the protein was not decided.

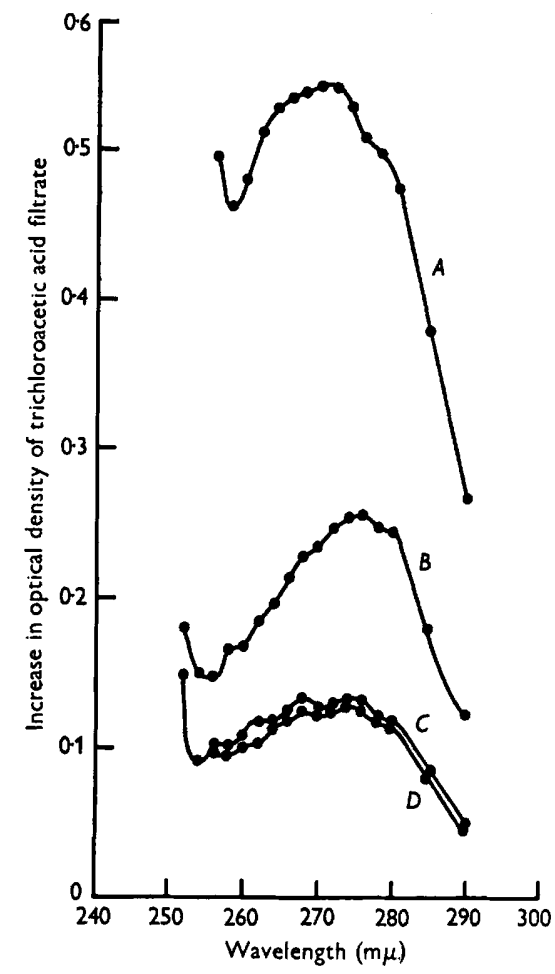

Fig. 3

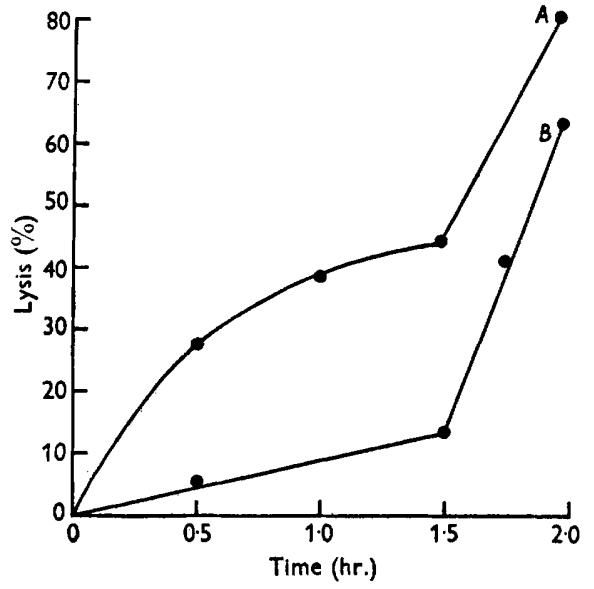

Fig. 4

Fig. 3. Ultraviolet absorption spectra of trichloroacetic acid-soluble material liberated by the streptomyces preparation from autoclaved Bact. coli in the presence $(A)$ and in the absence $(B)$ of manganese, and from autoclaved Staph. aureus in the presence $(C)$ and in the absence $(D)$ of manganese.

Fig. 4. Lysis of autoclaved Staph. aureus by ribonuclea se (curve $A$ from 0 to $1.5 \mathrm{hr}$.) and the streptomyces preparation (curve $A$ from 1.5 to $2 \mathrm{hr}$.), and by the streptomyces preparation alone (curve $B$ from 1.5 to $2 \mathrm{hr}$.).

Table 7. Effect of manganese (0.002 $\mathrm{M})$ on the proteolysis of fractions obtained from autoclaved Staph. aureus by treatment with $0.5 \mathrm{~N}-\mathrm{NaOH}$ for 20 min. at $56^{\circ}$ and $100^{\circ}$

\begin{tabular}{cl} 
Temperature & \multicolumn{1}{c}{ Fraction } \\
$\left({ }^{\circ}\right)$ & \multicolumn{1}{c}{ tested } \\
$\mathbf{5 6}$ & Insol. residue \\
& Extract \\
100 & Insol. residue \\
& Extract
\end{tabular}

Nondialysable nitrogen in fraction (\% of total)

$67 \cdot 5$

$32 \cdot 5$

$12 \cdot 0$

$88 \cdot 0$
Ratio: $\frac{\text { activity }+\mathrm{Mn}}{\text { activity }-\mathrm{Mn}}$ $1 \cdot 1$

$$
1 \cdot 1
$$$$
\text { 3.4 }
$$$$
\mathbf{3} \cdot \mathbf{9}
$$ 


\section{Attempts to purify and separate the streptomyces proteases}

Numerous attempts were made to separate and purify the streptomyces enzymes by salting out and adsorption, but they met with little success. An attempt was also made to take advantage of the fact that the manganeseactivated enzyme was more strongly adsorbed on to autoclaved Bact. coli than the caseinolytic enzyme (see Tai \& van Heyningen, 1951). The mixture of enzymes was adsorbed with autoclaved Bact. coli, the organisms were suspended in buffer and incubated at $37^{\circ}$ until they had all dissolved, and the resultant solution was again adsorbed with autoclaved Bact. coli. When this process was repeated once more a $\mathbf{1 5}$-fold concentration of the manganese-activated enzyme relative to the caseinolytic enzyme was obtained. However, this procedure had no practical value as the yields of enzyme were extremely low, and although there was a separation of the enzymes there was no increase in their activity per unit weight of non-dialysable nitrogen.

Many attempts were made to purify the enzymes by fractional precipitation with organic solvents under controlled conditions of ionic strength, temperature, $\mathrm{pH}$, protein concentration and solvent concentration. The two enzymes were not separated and at best a 4-fold increase in total enzyme activity was obtained when the enzymes were precipitated with $80 \%$ methanol ( $/ \mathrm{v}$ final concentration) at $\mathrm{pH} 4 \cdot 0$, temperature $-5^{\circ}$, and at an ionic strength equal to that of tapwater (about 0.005). With $80 \%$ methanol the yield of both enzymes was about $80 \%$; with $40 \%$ methanol the same purification was obtained, but the yield of enzymes was $25 \%$. The great solubility of both enzymes and their associated impurities in concentrated $\left(\mathrm{NH}_{4}\right)_{2} \mathrm{SO}_{4}$ solutions and in ethanol, methanol, and acetone prevented their purification.

\section{The role of ribonuclease in the lysis of Gram-positive organisms}

The preparation obtained by precipitating the streptomyces enzymes with $80 \%$ methanol at $\mathrm{pH} 4.0$ had ribonuclease activity (per $\mathrm{mg}$. non-dialysable nitrogen) equivalent to $1 / 2000$ th of that of a sample of crystalline pancreatic ribonuclease (kindly supplied by Prof. J. N. Davidson), and the yield of ribonuclease in this precipitate was at least $50 \%$ of that contained in the crude streptomyces culture filtrates. Jones et al. (1948) suggested that the lysis of Gram-positive organisms by actinomyces proteases was preceded by the removal of the Gram-staining material by ribonuclease. This could not be confirmed with the streptomyces preparation. When suspensions of autoclaved Staph. aureus (containing 2-3\% of Gram-negative cells) were lysed to the extent of $50 \%$ by the streptomyces preparation there was no change in the Gram-staining properties of the residual cells, and the trichloroacetic acidsoluble products absorbed ultraviolet light with a maximum at about $277 \mathrm{~m} \mu$. which is characteristic of proteins (see Fig. 3). On the other hand, when these cells were treated with small concentrations of crystalline pancreatic ribonuclease the trichloroacetic acid fraction absorbed intensely at $258 \mathrm{~m} \mu$. Crystalline ribonuclease did cause some decrease in the turbidity of a suspension 
of autoclaved Staph. aureus (see Fig. 4), but the concentration of ribonuclease required to cause $25 \%$ lysis was about 40,000 times as high as that in a streptomyces protease preparation that would cause the same amount of lysis in the same time.

Table 8. Decrease in size of autoclaved Bact. coli cells during incubation with the streptomyces preparation

\begin{tabular}{|c|c|c|c|}
\hline \multicolumn{4}{|c|}{ (Temperature of incubation $37^{\circ}$.) } \\
\hline $\begin{array}{l}\text { Time of } \\
\text { incubation } \\
\text { (min.) }\end{array}$ & $\begin{array}{c}\text { Lysis } \\
(\%)\end{array}$ & $\begin{array}{l}\text { Number of } \\
\text { cells/ml. } \\
\text { suspension }\end{array}$ & State of cells \\
\hline o & $\mathbf{0}$ & $2.5 \times 10^{9}$ & Normal \\
\hline 20 & 38 & $2.6 \times 10^{9}$ & - \\
\hline 45 & 58 & $2 \cdot 6 \times 10^{9}$ & - \\
\hline 60 & 63 & $2 \cdot 5 \times 10^{9}$ & Smaller, not elongated \\
\hline
\end{tabular}

Reduction in size of cells during bacteriolysis

When autoclaved Bact. coli cells were partially lysed by the streptomyces preparation there was apparently no dissolution of the cells but rather a diminution in size. Table 8 shows that after $63 \%$ lysis there was no appreciable decrease in the total numper of cells. Dubos (1937) obtained similar results when Gram-positive cells (heat-killed pneumococci) were treated with trypsin.

I am grateful to Dr W. E. van Heyningen for advice and help, and to the Medical Research Council for a Studentship in Research Methods.

\section{REFERENCES}

BonN, G. V. R. (1951). Lysis caused by micro-organisms. D.Phil. Thesis: University of Oxford.

Crewther, W. G. \& Lennox, F. G. (1950). Preparation of crystals containing protease from Aspergillus oryzae. Nature, Lond. 165, 680.

Duвos, R. J. (1937). The autolytic system of pneumococci. J. exp. Med. 65, 873.

Jones, A. S., Swallow, A. J. \& WebB, M. (1948). The exocellular bacteriolytic system of soil actinomyces. 1 . The nature and properties of the lytic system. Biochem. Biophys. Acta, 2, 167.

Kunitz, M. (1947). Crystalline soybean trypsin inhibitor. II. General properties. J. gen. Physiol. 30, 291.

Stockdale, D. \& Dexter, J. (1938). Clowes and Coleman's Quantitative Chemical Analysis, 14th ed. London: Churchill.

TaI, T. Y. \& van HeYningen, W. E. (1951). Bacteriolysis by a species of Streptomyces. J. gen. Microbiol. 5, 110.

Vendrely, R. (1946). Congrès de Chimie biologique de Liège. Quoted by Stephenson, M. (1949). Bacterial Metabolism, 3rd ed., p. 148. London:Longmans, Green and Co.

Waksman, S. A. (1947). Microbial Antagonism and Antibiotic Substances, 2nd ed. New York: The Commonwealth Fund.

Welsch, M. (1947). Phénomènes d'antibiose chez les Actinomycètes. Gembloux: Imprimerie J. Duculot. 